\title{
PERFORMANCE OF QUARRY DUST ON SCC WITH METAKAOLIN
}

\author{
Puvvala SomaSekhar ${ }^{1} \&$ S. Shameem Banu ${ }^{2}$
}

\begin{abstract}
SCC is a type of concrete that can be placed in the form work and it passes through any obstruction by its own weight and does not require any vibration. Modern application of SCC is focused on high performance, better and more reliable and uniform quantity. Recognizing the lack of uniformity and complete compaction of concrete by vibration, researches at the university of Tokyo, Japan, started in late 1980's to develop SCC. By the year 2000, the SCC has become popular in Japan for prefabrication products and ready mixed concrete. The present study focuses on utilization of quarry dust and Metakaolin in SCC as a partial replacement of fine aggregate and cement respectively. Quarry dust is a by-product from the crushing process during quarrying activities is one of such materials. In recent days there were also been many attempts to use Metakaolin, it is not an industrial by product. Metakaolin has a partial replacement for cement to have higher workability, long term strength and to make the concrete more economically available. The present experiment is carried out to investigate the fresh and hardened properties of Self Compacting Concrete with 0 to $30 \%$ percentage of quarry dust as a replacement for fine aggregate and Metakaolin as partial replacement of cement. In this project, an attempt has been made to study the fresh and hardened properties such as flow ability, passing ability, compressive, tensile and flexural strength of Self compacting concrete.

Key wards: Quarry Dust, Metakaolin, self compacting concrete, EFNARC guide lines.
\end{abstract}

\section{INTRODUCTION}

Self compacting concrete is a concrete which can be placed and compacted under its self weight with no vibration effort. It has high workability that it can flow under its own weight. Self-Compacting concrete is a recent development in the construction industry. Since its first development in Japan during mid 1980's, SCC has gained wider acceptance in Japan, Europe and USA due to its inherently distinct advantages. Several European countries recognized the significance and potential of SCC developed in Japan. During 1989, they founded European federation of natural trade association representing producers and applicators of specialist building product (EFNARC).The utilization of SCC started growing rapidly. EFNARC, making use of broad practical experience of all members of Europe federation with SCC.. Quarry dust which is generally considered as a waste material after the extraction and processing of rocks can be used as a replacement for fine aggregate. Quarry Dust is a high pozzolanic material which can be used as partial replacement for cement.

\section{MATERIALS AND THEIR PROPERTIES}

\subsection{CEMENT}

The cement in broad sense can be described as a material with adhesive and cohesive properties, which is capable of binding mineral fragment into compact mass. There are several types of cements available in market. Among them ordinary Portland cement (OPC) of 43 grade conforming to IS 1226:1978 is used in our study.

\subsection{Metakaolin}

It is a valuable pozzolanic and thermally activated Alumino-Silicate material obtained by Calcining Kaolin clay within the temperature of $700^{\circ}-850^{\circ}$.It is a dehydroxylated form of the clay mineral kaolinite. Stone that are rich in kaolinite are known as china clay or kaolin. The particle size of metakaolin is smaller than cement particles, but not as fine silica fume.

Table 1 Chemical Composition of Cement and Metakaolin

\begin{tabular}{|l|l|l|l|l|l|}
\hline Composition & $\mathrm{Fe}_{2} \mathrm{O}_{3}$ & $\mathrm{SiO}_{2}$ & $\mathrm{Al}_{2} \mathrm{O}_{3}$ & $\mathrm{CaO}$ & $\mathrm{MgO}$ \\
\hline Cement & 4 & 23 & 7 & 62 & 3 \\
\hline Metakaolin & 4.3 & 52.4 & 36.1 & 0.1 & 0.84 \\
\hline
\end{tabular}

\footnotetext{
${ }^{1}$ M. tech, Structural Engineering, JNTU Kakinada

${ }^{2}$ Assistant Professor, JNTU Kakinada
} 
Table 2 Physical properties of Metakaolin and OPC43 grade cement

\begin{tabular}{|l|l|l|}
\hline Properties & Metakaolin & OPC 43 cement \\
\hline Specific surface $\left(\mathrm{m}^{2} / \mathrm{g}\right)$ & 2350 & 330 \\
\hline Specific gravity & 2.6 & 3.1 \\
\hline
\end{tabular}

\subsection{Fine aggregate}

Fine aggregate increases the volume of concrete and thus makes it cheaper. It fills the voids in concrete and gives density to concrete. It makes the mass homogeneous and improves the strength of concrete. The hardening process of concrete results from the chemical reaction between silica and cement constituents. The fine aggregate with maximum size of $4.75 \mathrm{~mm}$ is used.

\subsection{Coarse aggregate}

For structural concrete the common coarse aggregate used is crushed hard stone. Coarse aggregate with maximum size of $12 \mathrm{~mm}$ was used.

Table 3: Properties of coarse aggregate

\begin{tabular}{|l|l|l|}
\hline S. No & Description & Value \\
\hline 1 & Specific gravity & 2.82 \\
\hline 2 & Fineness modulus & 6.68 \\
\hline 3 & Nominal size & $12 \mathrm{~mm}$ \\
\hline
\end{tabular}

\subsection{Quarry dust}

Locally available quarry dust is used for this project. Quarry Rock Dust can be defined as residue, tailing or other non- voluble waste material after the extraction and processing of rocks to form fine particles less than $4.75 \mathrm{~mm}$. Quarry dust is fine rock particles. When boulders are broken into small pieces quarry dust is formed. It is gray in colour and it is like fine aggregate. Quarry dusts are produced during the extraction and processing of aggregates.

Table 4: Physical properties of Quarry Dust and Sand

\begin{tabular}{|l|l|l|}
\hline Physical properties & Quarry Dust & Sand \\
\hline Specific gravity & 2.56 & 2.67 \\
\hline Water absorption & 1.0 & Nil \\
\hline Bulk density $\left(\mathrm{Kg} / \mathrm{m}^{3}\right)$ & 1730 & 1460 \\
\hline
\end{tabular}

\subsection{Conplast SP430}

Conplast SP430 is used for this investigation. It is used for obtaining high degree workability and its retention are required, where delays in transportation or placing are likely or when high ambient temperatures cause rapid slump loss. It facilitates production of high quality concrete.

\subsection{Viscosity Modifying Agent}

Admixture added to fresh concrete to increase cohesion and segregation resistance. Auromix 400 is used in this investigation. Auromix 400 is a unique combination of the latest generation super plasticizers, based on a polycarboxylic ether polymer with long lateral chains. This greatly improves cement dispersion.

\section{MIX DESIGN}

The mix design is done as per the EFNARC guidelines. As there is no standard proportioning method is available for selfcompacting concrete various trial mixes are done as per the guidelines and finally mix proportion is achieved. Table 5 shows the mix proportion of the self compacting concrete.

M1- Nominal SCC mix (8\% metakaolin and 0\% quarry dust) M2- 8\% Metakaolin and 10\% quarry dust M3- $8 \%$ Metakaolin and 20\% quarry dust M4- $8 \%$ Metakaolin and 30\% quarry dust 
Table 5: Shows the mix proportions of the self- compacting concrete.

\begin{tabular}{|c|c|c|c|c|c|c|}
\hline \multirow{2}{*}{ S. No } & \multirow{2}{*}{ Material } & \multirow{2}{*}{ Units } & \multicolumn{4}{|c|}{ Material Quantities } \\
\hline & & & M1 & M2 & M3 & M4 \\
\hline 1 & Cement & $\mathrm{Kg} / \mathrm{m}^{3}$ & 460 & 460 & 460 & 460 \\
\hline 2 & Metakaolin & $\mathrm{Kg} / \mathrm{m}^{3}$ & 40 & 40 & 40 & 40 \\
\hline 4 & Fine aggregate & $\mathrm{Kg} / \mathrm{m}^{3}$ & 873.2 & 785.8 & 698.56 & 611 \\
\hline 5 & Quarry Dust & $\mathrm{Kg} / \mathrm{m}^{3}$ & 0 & 87.32 & 174.64 & 261.96 \\
\hline 6 & Coarse aggregate & $\mathrm{Kg} / \mathrm{m}^{3}$ & 821.2 & 821.2 & 821.2 & 821.2 \\
\hline 7 & Water & $\mathrm{lit} / \mathrm{m}^{3}$ & 200 & 200 & 200 & 200 \\
\hline 8 & Super Plasticizer & $\mathrm{lit} / \mathrm{m}^{3}$ & 3.5 & 3.5 & 3.5 & 3.5 \\
\hline 9 & viscosity modifying agent & lit $/ \mathrm{m} 3$ & 2.5 & 2.2 & 2.2 & 2.5 \\
\hline
\end{tabular}

\section{FRESH CONCRETE PROPERTIES OF SCC}

\subsection{Slump flow test}

The slump flow measures the flow spread. It indicates the free, unrestricted deformability within a defined flow distance. The slump cone has $20 \mathrm{~cm}$ bottom diameter, $10 \mathrm{~cm}$ top diameter and $30 \mathrm{~cm}$ in height. Fill the cone with the sample from the bucket without any external compacting action such as rodding or vibrating. The surplus concrete above the top of the cone should be struck off, and any concrete remaining on the base plate should be removed. After a short rest (no more than 30 seconds), lift the cone perpendicular to the base plate in a single movement, in such a manner that the concrete is allowed to flow out freely without obstruction from the cone. Thesubsequent diameter of the spread is measured in two perpendicular directions.

\subsection{L-box test}

Fill the vertical part of the L-box with fresh concrete. Now the sliding gate is lifted and the concrete flows from the vertical part to the horizontal part. The height of the section at the end of the horizontal section represents $\mathrm{h} 2(\mathrm{~mm})$ and the height of the vertical section represents $\mathrm{h} 1 \mathrm{(mm})$. The ratio of $\mathrm{h} 2 / \mathrm{h} 1$ is known as blocking ratio.

\section{3 -funnel test}

The V-funnel flow time is the period a defined volume of SCC needs to pass a narrow opening and gives an indication of the filling ability of SCC provided that blocking and/or segregation do not take place; the flow time of the V-funnel test is to some degree related to the plastic viscosity. Fill the funnel completely with a representative sample of SCC without applying any compaction or rodding. Remove any surplus of concrete from the top of the funnel using the straight edge. Open the gate after a waiting period of $(10 \pm 2)$ seconds. Start the stopwatch at the same moment the gate opens. Look inside the funnel and stop the time at the moment when clear space is visible through the opening of the funnel. The stopwatch reading is recorded as the V-funnel flow time. Do not touch or move the V-funnel until it is empty.

Table 6: Fresh property test results of SCC

\begin{tabular}{|c|c|c|c|c|c|c|c|}
\hline \multirow[b]{2}{*}{ S.NO } & \multirow[b]{2}{*}{ TEST METHOD } & \multirow[b]{2}{*}{ PROPERTY } & \multirow[b]{2}{*}{ UNITS } & \multicolumn{4}{|c|}{ Test values } \\
\hline & & & & M1 & M2 & M3 & M4 \\
\hline 1 & Slump Flow & Filling Ability & $\mathrm{mm}$ & 643 & 647 & 694 & 720 \\
\hline
\end{tabular}




\begin{tabular}{|l|l|l|l|l|l|l|l|}
\hline 2 & V-Funnel at $\mathrm{T}_{0}$ & Segregation & $\sec$ & 11 & 10 & 9 & 9 \\
\hline 3 & L-Box & Passing ability & $\left(\mathrm{h}_{2} / \mathrm{h}_{1}\right)$ & 0.8 & 0.89 & 0.9 & 0.73 \\
\hline
\end{tabular}
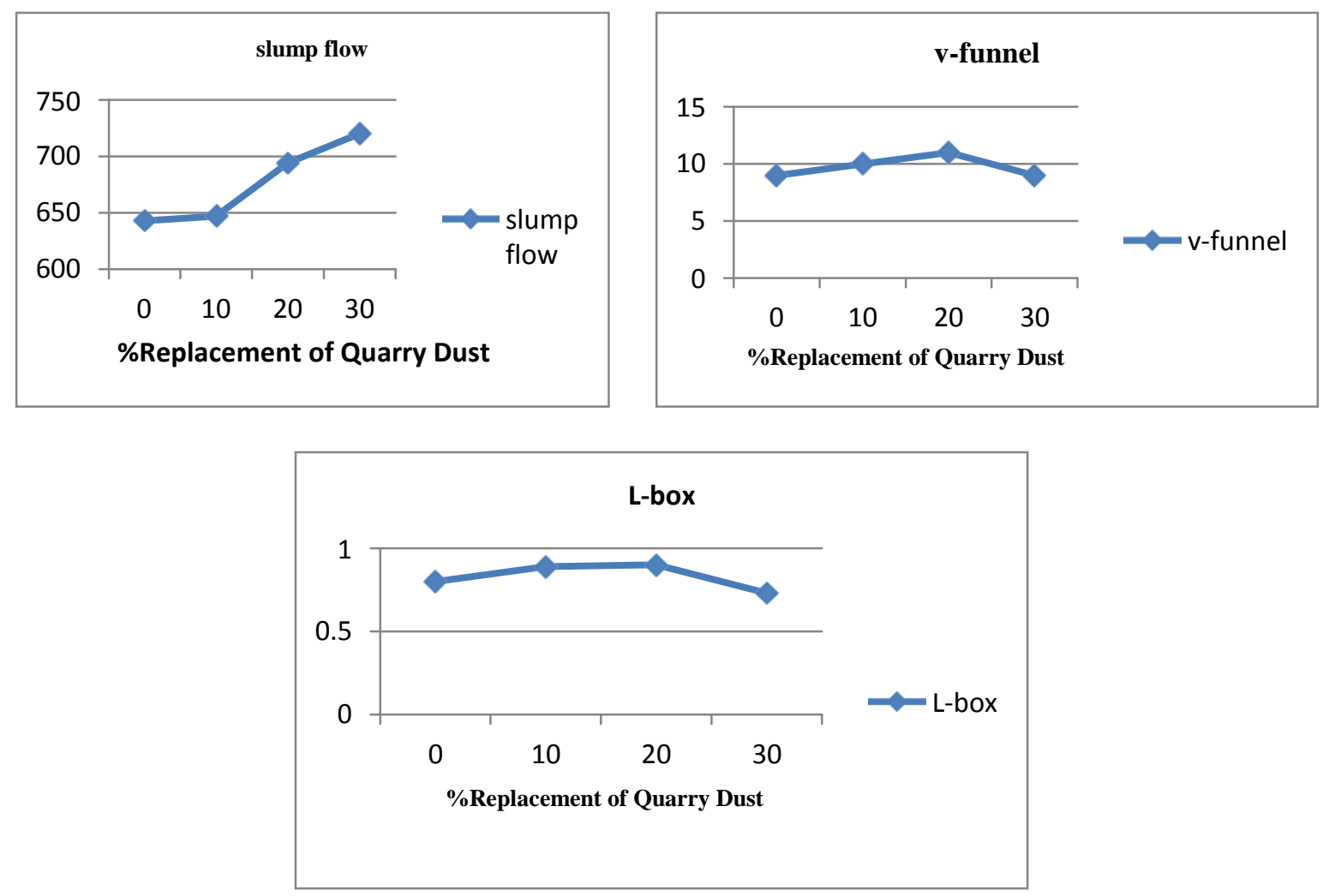

\section{EXPERIMENTAL INVESTIGATIONS ON HARDENED CONCRETE}

\subsection{Compressive strength test}

Compressive strength test is the most common test conducted on hardened concrete. Cube specimens of size $150 \mathrm{~mm} x$ $150 \mathrm{~mm} \times 150 \mathrm{~mm}$ were cast for finding the compressive strength after curing for 7 and 28 days. Then the specimen was placed between the jaws of compression testing machine of $2000 \mathrm{KN}$ capacity. Compressive load was given till the specimen failed. The failure load was noted as shown in the display of CTM. The compressive strength of three cubes was calculated from the average failure load of cubes.

Cube strength $=$ load $/$ area of cross section

\subsection{Split Tensile Strength}

Split Tensile Strength was used to determine the tensile strength of concrete. Cylindrical specimens of size $150 \mathrm{~mm}$ diameter and $300 \mathrm{~mm}$ height were used in this test. For each mix 3 specimens were cast and cured for 28days.Tensile strength test was carried out in a $2000 \mathrm{KN}$ capacity compression testing machine in which the specimens were placed in such a way that its axis was horizontal. The load was applied uniformly at a constant rate until failure by splitting along the vertical diameter took place. The failure load was recorded and the splitting tensile strength was computed.

Split tensile strength $\mathrm{Spt}=2 \mathrm{xP} /(\Pi \mathrm{xDxL})$ Where, $\mathrm{P}=$ Compressive load on the cylinder

$\mathrm{L}=$ Length of cylinder $\mathrm{D}=$ Diameter of cylinder

\subsection{Flexural strength test}

For flexural strength test on prism specimens of dimension 500x500x700 mm were cast. The specimens were cast and were transferred to curing tank wherein they were allowed to cure for 28 days. These flexural strength specimens were tested on Flexural testing machine. Load and corresponding deflections were noted up to failure. In each category three Prisms were tested and their average value is calculated. The flexural strength test is done as per IS: 516-1959

The flexural strength was calculated as follows

Flexural strength $(\mathrm{MPa})=\mathrm{PL} / \mathrm{bd}^{2}$ 
When "a" is greater than $13.3 \mathrm{~cm}$ for a $10.0 \mathrm{~cm}$ specimen, or

$\mathrm{F}_{\mathrm{b}}=(3 \mathrm{Pxa}) /\left(\mathrm{bxd}^{2}\right)$

When "a" is less than $13.3 \mathrm{~cm}$ but greater than $11.0 \mathrm{~cm}$ for a $10.0 \mathrm{~cm}$ specimen Where, $\mathrm{P}=$ Failure load, $\mathrm{L}=$ Length of the specimen, $b=$ width of specimen $=100 \mathrm{~mm} d=$ depth of specimen $=150 \mathrm{~mm}$

\subsection{Durability test}

Durability might be defined as the ability to maintain satisfactory performance over an extended service of life. Satisfactory performance is related to intended use. All types of concretes are vulnerable to varying degrees of attack by sulphates, chlorides and etc., Acids erode the surface of the concrete by dissolving the cement paste and calcareous aggregates (if these are used).In general the higher the concentration, the greater the degree of attack. The factors influencing the durability of concrete are: The environment, cover to embedded steel, type and quality of constituent materials, cement content and water powder ratio of the concrete, workmanship to obtain full compaction and efficient curing, size and shape of the member. For durability of concrete, the cubes are cast and cured initially for 28 days and then cured in sea water for 28 days. After that the compressive strength test is done on the cubes to find percentage of deterioration

\section{RESULTS AND DISCUSSIONS}

The test results of compressive strength, split tensile strength and flexural strength of cubes and prisms for replacement of cement with $8 \%$ of metakaolin as constant rate and replacement of fine aggregate with quarry dust varying from $0 \%$ to $30 \%$ with at the rate of $10 \%$ are discussed in this chapter.

\subsection{Compressive strength test}

The compression test was conducted on various specimens with replacements of cement with Metakaolin as $8 \%$ and fine aggregate in Quarry Dust upto $30 \%$.

Table 7: Compressive Strength Test Results of Concrete Cubes

\begin{tabular}{|l|l|l|l|}
\hline \multirow{2}{*}{$\begin{array}{l}\text { Mix } \\
\text { Notation }\end{array}$} & \multicolumn{3}{|l|}{ Compressive Strength(MPa) } \\
\cline { 2 - 4 } & 7 Days & 28 Days & 56 days \\
\hline M1 & 34.8 & 36.9 & 40.2 \\
\hline M2 & 35.3 & 40.8 & 41.3 \\
\hline M3 & 36.6 & 42.4 & 44.6 \\
\hline M4 & 33.5 & 35.9 & 43.2 \\
\hline
\end{tabular}

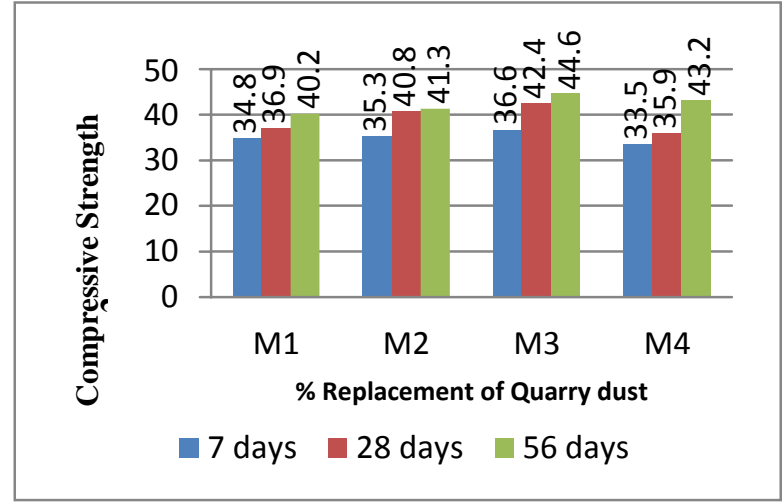

6.2 Split tensile strength

Table 8 and graph shows the results of split tensile strength for various specimens with different proportions.

\begin{tabular}{|l|l|l|l|}
\hline \multirow{2}{*}{$\begin{array}{c}\text { Mix } \\
\text { Notation }\end{array}$} & \multicolumn{3}{|l|}{ Split Tensile Strength(MPa) } \\
\cline { 2 - 4 } & 7 Days & 28 Days & 56days \\
\hline M1 & 1.7 & 2.2 & 2.4 \\
\hline M20 & 1.8 & 2.7 & 2.9 \\
\hline M3 & 1.9 & 2.9 & 3.1 \\
\hline M4 & 1.7 & 2.2 & 2.1 \\
\hline
\end{tabular}

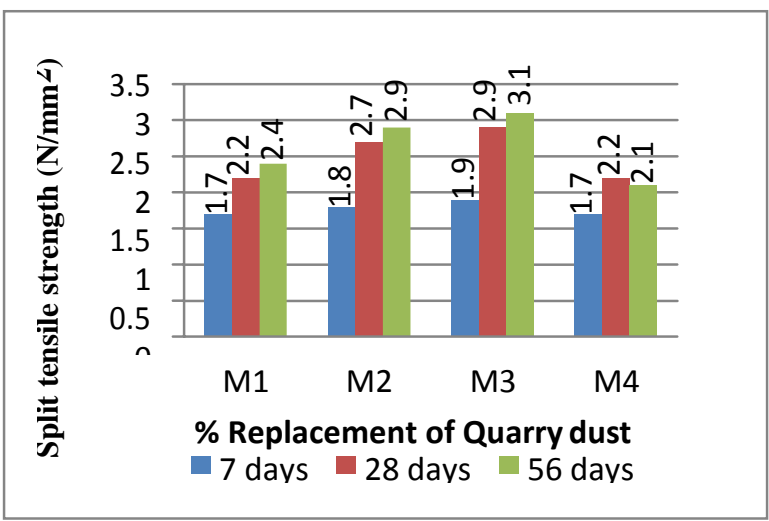




\subsection{Flexural strength test}

Table 9 and graph shows the results of flexural strength for various specimens with different proportions.

\begin{tabular}{|l|l|l|l|}
\hline \multirow{2}{*}{$\begin{array}{l}\text { Mix } \\
\text { Notation }\end{array}$} & \multicolumn{3}{|c|}{ Flexural Strength (MPa) } \\
\cline { 2 - 4 } & 7 Days & 28 Days & 56days \\
\hline M1 & 4.1 & 4.2 & 4.9 \\
\hline M2 & 4.2 & 4.5 & 5.2 \\
\hline M3 & 4.5 & 5.2 & 5.5 \\
\hline M4 & 3.9 & 3.8 & 4.5 \\
\hline
\end{tabular}

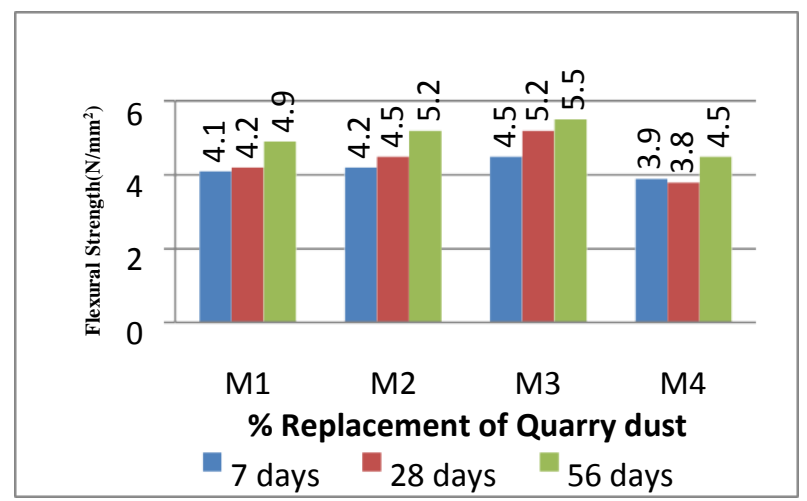

\subsection{Durability test}

To determine the durability of concrete, the cubes were cured in normal water for 28 days. After 28 days, they were taken out and dried for 24 hours later they were immersed in sea water to for 28 days. Before and after placing in sea water the cubes weights are noted down. The compressive strength test was done on the cubes which were cured in sea water for 28 days.

Table 10 chemical composition of sea water

\begin{tabular}{|l|l|l|l|}
\hline Composition & $\mathrm{P}^{\mathrm{H}}$ & Chloride content & Sulphate content \\
\hline Concentration $(\mathrm{mg} / \mathrm{l})$ & 8.30 & 19.34 & 2701 \\
\hline
\end{tabular}

Table 11: \% loss strength and weight of cubes

\begin{tabular}{|l|l|l|}
\hline$\%$ Replacement & \% loss of Compressive Strength & \% Loss of Weight \\
\hline $0 \%$ QD & 3.26 & 0.23 \\
\hline $10 \%$ QD & 4.02 & 0.80 \\
\hline $20 \%$ QD & 2.86 & 0.46 \\
\hline $30 \%$ QD & 2.05 & 0.58 \\
\hline
\end{tabular}
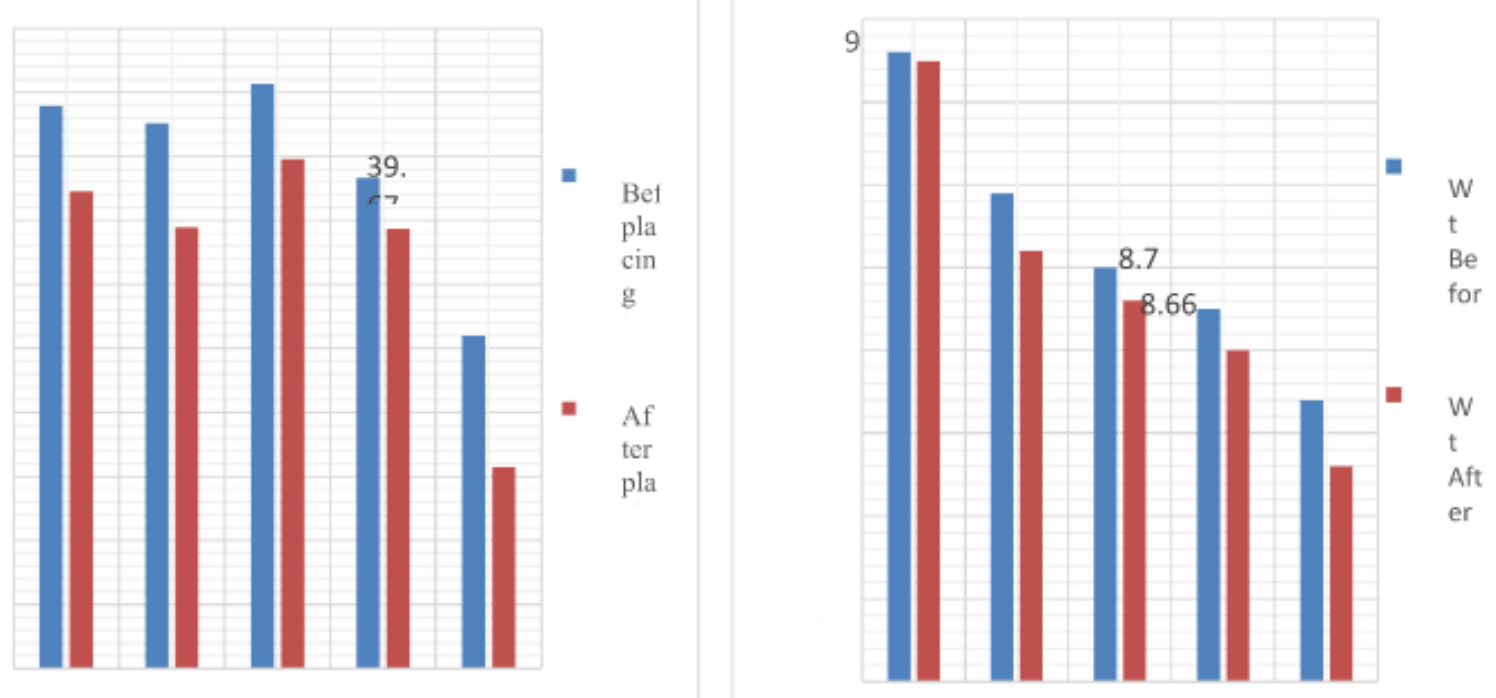


\section{CONCLUSIONS}

1) Workability increases with the increase in Quarry Dust upto $20 \%$ replacement in fine aggregate.

2) The optimum is 20\% of Quarry Dust and 8\% of Metakaolin, further increase in Quarry Dust leads to to segregation and reduction in strength

3) The compressive, split tensile and flexural strength results were found optimum at $8 \%$ of metakaolin in cement and $20 \%$ replacement in fine aggregate.

4) Compressive strength increases upto $20 \%$ replacement at the age of 7 days (5.1\%) and 28 days (14.9\%) and gradually decreases with increases in Quarry dust replacement.

5) Split tensile strength increases upto $20 \%$ replacement at the age of 7 days (11.7\%) and 28 days (31.5\%) and gradually decreases with increases in Quarry dust replacement.

6) Flexural strength increases upto $20 \%$ replacement at the age of 7 days $(9.7 \%)$ and 28 days (23.6\%) and gradually decreases with increases in Quarry dust replacement.

7) For 28 days of curing in sea water, strength reduction and weight reduction in SCC is less when compare to normal concrete

8) Due to increasing percentage of Quarry Dust it leads to decreasing of strength and causes bulging in SCC.

\section{REFERENCES}

[1] Abhishek Jain, Nazrul Islam (2013). "Use of quarry dust as partial replacement of Sand in Cement mortar". International Journal of Innovative Research in Science, Engineering and Technology volume 2, Issue 5.

[2] Aijaz Ahmad Zende, R.B. Khadhirnaikar, "An overview of the properties of Self compacting concrete" International Organization of Scientific and Research Journal of Mechanical and Civil Engineering, 2014.Indian Standard code IS 10262-2009.

[3] KapilLakra, Vaibhav Gupta (2016). "Effect of Partial Replacement of fine aggregate by quarry dust". International Journal of Engineering Science and Computing Volume 6 Issue No. 8.

[4] Kim HS, Lee SH, Moon HY.Strength properties and durability aspects of high strength concrete using Korean Metakaolin. Construction Build Mater 2007;21:1713-23.

[5] Krishna Murthy. N, Narasimha Rao A.V, Ramana Reddy I .Vand, Vijaya sekhar Reddy.M, "Mix Design Procedure for Self Compacting Concrete", International Organization of Scientific and Research Journal of Engineering, Volume 2, Issue 9, and September 2012.

[6] Needhidasan Santhanam, Manoj Nallanathel and Monirupa Ananya, "Self compacting concrete- A Boon to construction Industry", International Global Journal For Research Analysis, Volume 3, Issue 9, September 2014.

[7] Paratibha Aggarwal, Rafat SIDDIQUE, Yogesh AGGARWAL, Surinder M GUPTA, "Self-Compacting Concrete - Procedure for Mix Design", Leonardo Electronic Journal of Practices and Technologies, ISSN 1583-1078.

[8] Poon CS, Kou SC, Lam. Compressive strength, chloride diffusivity and pore structure of high performance metakaolin and silica fume concrete. Conce Build matert 2006;20:858-65.

[9] Prema kumar W.P, Mr.Ananthaya M.B, Mr. Vijay K, "Effect of replacing sand by quarry dust on the compressive strength of concrete and flexural strength of reinforced concrete beams", International Journal of Research in Engineering and Technology, ISSN: 2278-0181, Vol,3 Issue 7, July 2014.

[10] Sahil Goyal, Keshav Singh, Ahmad Hussain, Priyanka Ramkripal Singh, " Study on Partial Replacement of Sand with stone dust on Compressive strength of Concrete", International Journal of Research in Engineering \& Advanced Technology, Volume 3, Issue 2, April-May, 2012. 